\title{
RULES ON COMPETITION IN THE EU AGRICULTURE SECTOR. LATEST DEVELOPMENTS IN THE LIGHT OF THE CAP REFORM 2014-2020
}

\author{
NORMAS DE COMPETENCIA EN EL SECTOR DE AGRICULTURA \\ DE LA UE. NOVEDADES A LA LUZ DE LA TAPA DE LA REFORMA \\ 2014-2020
}

\author{
ERYK KOSIŃSKI*
}

\begin{abstract}
SUMARIO: I. INTRODUCCIÓN. EL CONCEPTO DE COMPETICIÓN ECONÓMICA. II. EL ÁMBITO MATERIAL Y PERSONAL DE LA POLÍTICA AGRÍCOLA EN LA UE. III. LAS NORMAS DE COMPETENCIA EN EL SECTOR AGRÍCOLA DE LA UE. IV. LOS ÚLTIMOS AVANCES EN POLÍTICA AGRÍCOLA DE LA UE. V. CONCLUSIONES FINALES.
\end{abstract}

SUMMARY: I.INTRODUCTION. THE CONCEPT OF ECONOMIC COMPETITION. II. EU GRICULTURAL POLICY. MATERIAL AND PERSONAL SCOPE. MAIN OBJECTIVES. III. COMPETITION RULES IN THE EU AGRICULTURAL SECTOR. IV. LATEST DEVELOPMENTS WITHIN EU AGRICULTURAL POLICY. V.FINAL CONCLUSIONS.

Resumen: Existen diferentes conceptos de competencia presentada en el artículo. Por otra parte, el artículo presenta diversos objetivos de política de competencia y de la normativa de protección de la competencia. A continuación, se describen sus objetivos y la política agrícola común. El objetivo de dicha descripción es comparar objetivos generales de la regulación de la protección de la competencia con los objetivos de la política agrícola común y Desarrollo Rural. Notable, que esos objetivos no son que lejos de uno a por lo tanto, las normas de competencia tienen ciertos objetivos sociales y políticos así. Según arte. 42 del TFUE todas las reglas de competencia se aplican a la producción de y el comercio de productos agrícolas sólo en la medida determinada por el Parlamento Europeo y el Consejo general conforme a los principios y objetivos de la política agrícola común y Desarrollo Rural. Por lo tanto, los objetivos de la política agrícola de la UE prevalecen sobre las normas de competencia general (caso 139/79 Maizena GmbH v. Consejo). Un ámbito específico de aplicación de la exclusión de las normas de competencia general está regulado por Reglamento (CE) n ${ }^{\circ}$ 1184/2006 del Consejo, de 24 de julio de 2006. Bajo mencionado Reglamento núm. 1184/2006 organizaciones de mercado agrícola nacional y los acuerdos, decisiones y prácticas que son indispensables para lograr los objetivos de la política agrícola común, y las organizaciones y asociaciones de agricultores están excluidas de prohibición establecido por el arte. $101 \mathrm{~s} 1$ de la TFUE. La exclusión no abarca la prohibición del arte. 102 del seminario. La organización

\footnotetext{
* Professor at Law and Administration Faculty of Adam Mickiewicz University in Poznan, and Visiting Professor of World Economy and Regional Industrial Policy Department of Peter the Great St.

Petersburg Polytechnic University in St. Petersburg, Russian Federation.
}

Revista de Estudios Jurídicos no 15/2015(Segunda Época)

ISSN 2340-5066. Universidad de Jaén (España)

Versión electrónica: rej.ujaen.es 
de los mercados agrícolas de EU es proporcionada por Reglamento $n^{0}$ 1308/2013 del Parlamento Europeo y del Consejo, de 17 de diciembre de 2013. Uno de los buenos ejemplos de organización del mercado es el mercado diario (llamado ' paquete de la leche'). La reforma de la PAC 2014-2020 es para garantizar la competitividad y sostenibilidad del sector agropecuario mediante la mejora de la focalización y eficiencia de instrumentos de política. La reforma prevé la supresión gradual de las restricciones de producción (cuotas) en ciertos mercados (diario, azúcar, vino). Sin embargo, no hay ninguna liberalización real amueblado. Competencia en el sector agrícola sigue siendo 'competencia regulada de estado'.

Abstract: There are different concepts of competition presented in the article. Moreover, the article presents different objectives of competition policy and of competition protection regulations. Then, the Common Agricultural Policy and its objectives are described. The goal of mentioned description is to compare general goals of competition protection regulation with the objectives of Common Agricultural Policy and Rural Development. Noteworthy, those goals are not that far from each other hence the competition rules have certain social and political objectives as well. According to art. 42 of TFEU all competition rules shall apply to production of and trade in agricultural products only to the extent determined by the European Parliament and the Council in compliance with general principles and objectives of the Common Agricultural Policy and Rural Development. Therefore, the objectives of EU agricultural policy prevail over the general competition rules (Case 139/79 Maizena GmbH v. Council). A specific scope of the exclusion from the EU general competition rules is regulated by Council Regulation (EC) No. 1184/2006 of 24 July 2006. Under mentioned Regulation No. 1184/2006 national agricultural market organizations, and agreements, decisions and practices which are indispensable to accomplish the objectives of Common Agricultural Policy, and farmers' organizations and associations are excluded from prohibition laid down by art. 101 sec 1 of the TFEU. The exclusion does not encompasses prohibition from art. 102 of the TFUE. The EU organisation of the agricultural markets is provided by Regulation No. 1308/2013 of the European Parliament and of the Council of 17 December 2013. One of good examples of market organisation is the diary market (so-called 'Milk Package'). The CAP Reform 2014-2020 is to guarantee competitiveness and sustainability of the agricultural sector by improving the targeting and efficiency of policy instruments. The reform provides for gradual removal of production constraints (quotas) in certain markets (sugar, diary, wine). Nevertheless, there is no real deregulation furnished. Competition in agricultural sector still remains 'state regulated competition'.

Palabras clave: agricultura; sector agropecuario; competencia; Política agrícola y Desarrollo Rural; normas generales de la protección de la competencia; normas específicas del sector de la competición.

Key words: agriculture; agricultural sector; competition; Common Agricultural Policy and Rural Development; general rules of the competition protection; sector specific rules of the competition

\title{
I. INTRODUCTION. THE CONCEPT OF ECONOMIC COMPETITION
}

\author{
Revista de Estudios Jurídicos no 15/2015(Segunda Época) \\ ISSN 2340-5066. Universidad de Jaén (España) \\ Versión electrónica: rej.ujaen.es
}


The term 'competition' takes its roots in Latin, where it meant originally 'common quest'. Nowadays the term 'competition' is generally understood as "a contest between organisms, animals, individuals, groups, etc., for territory, a niche, or a location of resources, for resources and goods, mates, for prestige, recognition, awards, or group or social status, for leadership. Competition is the opposite of cooperation"2. As in strictly economic sense the term competition means "the rivalry among sellers trying to achieve such goals as increasing profits, market share, and sales volume by varying the elements of the marketing mix: price, product, distribution, and promotion", "the effort of two or more parties acting independently to secure the business of a third party by offering the most favorable terms" ${ }^{3}$. According to great economist Alfred Marshall competition means just 'contest' 4 .

Robert H. Bork in his fundamental essay "The Antitrust Paradox: A Policy at War with Itself” (1978) distinguishes five major meanings of term „competition”. Firstly, competition is 'the process of rivalry'. Secondly, it is "the absence of restraint over one firm's economic activities by another firm". Thirdly, it is "a state of the market in which an individual buyer or seller does not influence price by his purchases or sales”. Fourthly, competition means a state in which given markets and sectors of the economy are fragmented into small units (atomization of the market). Lastly, competition is "a state of affairs in which consumer welfare cannot be increased by moving to alternative state of affairs through judicial decree" 5 .

Some economists say that the term of competition is irrelevant in fact. What is of a big importance these are characteristics, features of competition. Great Polish economist Professor Adam Noga points at some characteristics of competition like fear of competitors that motivates to more effective action, lack of enough space for all undertakings in a given sector of the economy, selection of undertakings and adjustment to the buyers' needs ${ }^{6}$.

Robert Bork and Ward S. Bowman rightly state “(...) that is the essential mechanism of competition and its prime virtue that more efficient firms take business away from the less efficient" ${ }^{\text {7 }}$.

Undoubtedly, a term 'competition' holds many meanings coming out of different points of view and from different scientific fields, like economy, sociology, political sciences, physics, chemistry, natural sciences, biology, etc.

Nevertheless, from a juridical point of view, it is rather crucial and necessary to define

\footnotetext{
${ }^{1}$ See THE LISBON GROUP, Granice Konkurencji (Limits to Competition, Polish edition), Warszawa,1996, p. 5 and p. 13. According to Latin dictionaries verb 'competo' (competo, competere, competivi, competitus) means, inter alia, 'to solicit, to contest together, jointly', 'meet; happen at same time, coincide; agree; be candidate together'. WHITAKER W., “AbleMedia English-Latin Latin-English Dictionary: Competition”, retrieved on February 2, 2015, in http://ablemedia.com/ctcweb/showcase/wordsonline.html.

${ }^{2}$ WIKIPEDIA, “Competition”, retrieved on February 2, 2015, in http://en.wikipedia.org/wiki/Competition.

3 Ibidem. In addition: "Mirriam-Webster On-line Dictionary", retrieved on February 1, 2015, in http://www.merriam-webster.com/dictionary/competition.

${ }^{4}$ MARSHALL, A., Zasady ekonomii (Principles of economy), Volume I, Warszawa, 1925, p. 5.

${ }^{5}$ BORK, R.H., The Antitrust Paradox: A Policy at War with Itself, New York, 1978, p. 58 ff. See on concept of consumer welfare: BORK, R.H., "Resale Price Maintenance and Consumer Welfare”, The Yale Law Journal, Vol. 77/1968, pp. 950-952. See additionally on concept of consumer welfare (and on so-called 'total welfare'): GORMSEN LOVDAHL, L., A Principled Approach to Abuse of Dominance in European Competition Law, Cambridge, 2010, pp. 20-58; and AKMAN, P., The Concept of Abuse in EU Competition Law. Law and Economic Approaches, Oxford and Portland, Oregon, 2012, pp. 11-48.

${ }^{6}$ NOGA, A., "Piąta fala konkurencji”, Roczniki Kolegium Analiz Ekonomicznych, Vol. 11/2003, p. 138.

${ }^{7}$ BORK, R.H., BOWMAN, W.S., "The Crisis in Antitrust”, Columbia Law Review, No. 3 (Vol. 65)/1965, p. 364.
} 
competition as to know what is a major goal of any law that is to protect competition.

Even though competition laws all over the world are a subject to strong globalization process and, henceforward, are much alike and standardized in their core elements ${ }^{8}$, notions of major goals of competition regulation are often differing among themselves.

It is noteworthy that the first modern competition law in the history, namely American Sherman Act of $1890^{9}$, was not merely an act of the Congress which just regulated market, but it was „... an expression of a social philosophy, an educative force, and a political symbol of extraordinary potency" ${ }^{\prime 10}$. Moreover, mentioned law was adopted under a very strong social pressure $^{11}$, put especially by American farmers in the second half of XIX (e.g. the National Grange of the Patrons of Husbandry ${ }^{12}$ ).

In majority of countries the competition law is based on two crucial prohibitions: a prohibition of anticompetitive agreements and a prohibition of an abuse of a dominant position (competition protection system based on the prohibition principle; germ. Verbotsprinzip). Nonetheless, there are still countries where there is competition law based on the system of control of abuses (germ. Missbrauchsprinzip) ${ }^{13}$.

The most universal system adopted by vast majority of countries all over the world refers to prohibitions (relative prohibition of anticompetitive agreements and rather per se prohibition of an abuse of a dominant position). This path is followed by the Treaty on Functioning of the European Union (henceforward: TFEU or 'the Treaty'), namely articles 101-102.

As far as the objectives of modern competition law concerned, there may be two clusters of objectives. First of all, there are objectives of economic nature (strictly economic goals), among which there are such elements (values) as: free market competition, consumer welfare, economic effectiveness (maximization of economic effectiveness) ${ }^{14}$. The point is, however, how the concept of 'competition' is understood. Most often competition is understood as a 'perfect competition', meaning an atomistic market where there is unlimited number of economic units (numerous firms) and no "individual or firm could unilaterally influence

\footnotetext{
${ }^{8}$ See e.g. GERBER, D.J., "Europe and the Globalization of Antitrust", Connecticut Journal of International Law, Vol. 14/1999, p. 15 ff. See additionally following works: GERBER, D.J., "Constitutionalizing the Economy: German Neoliberalism, Competition Law and the 'New' Europe”, The American Journal of Comparative Law, Vol. 42/1994, p. 25 ff; GERBER, D.J., "Integration, Disintegration and the Protection of Competition: Of Images, Stories and Myths", Chicago-Kent Law Review, Vol. 68/1992, p. 229 ff; and GERBER, D.J., "Antitrust Law and Economic Analysis: The Swedish Approach”, Hastings International and Comparative Law Review. Vol. 8/1984, p. $1 \mathrm{ff}$.

9 July 2, 1890, ch 647, §§ 1-7, 26 Stat. 210. Title 15, United States Code (U.S.C.) Sections 1-7.

${ }^{10}$ BORK, R.H., BOWMAN, W.S., supra, p. 364.

${ }^{11}$ See FURSE M., "The Role of Competition Policy: A Survey", European Competition Law Review, No. 4/1996, p. 254. See additionally: AREEDA, PH., KAPLOW, L., Antitrust Analysis. Problems, Text, Cases. Fifth Edition, Cambridge, 1997, p. 46.

${ }^{12}$ The organization (or movement) named 'The National Grange of the Patrons of Husbandry' was founded by Olivier Hudson Kelly in XIX c. There were approximately 1.5 million farmers in mentioned organization, mainly from the western states of the USA. See DEMPSEY, P.S., "Transportation: A Legal History", Transportation Law Journal, Vol. 30/2003, pp. 260-261, p. 263.

${ }^{13}$ Form example, the Swiss Cartel Act (Kartellrecht) of 1996 is based on the concept of control of abuses. See FRICK, T.A., BIRKHÄUSER, N., "New Developments in Swiss Competition Law and Foreign Undertakings", Comparative Law Yearbook of International Business, Vol. 26/2004, p. 255 ff.

${ }^{14}$ See on economic effectiveness: AREEDA, PH., "Introduction to Antitrust Economics", Antitrust Law Journal, Vol. 52/1983, pp. 524-525; and: AREEDA, PH., KAPLOW, L., supra, pp. 17 -18.
} 
prices, output, or any other terms of trade" 15 . Many economists prefer the concept of so called 'workable competition' or 'effective competition' which are concepts trying to reconcile both imperfections of the market in the imperfect world with the ideal of perfect, atomistic competition ${ }^{16}$.

The second cluster is of a social and political nature. Among those objectives it is worth to point at the aid for small and medium businesses, equal dispersion of economic and political power (redistribution of wealth, distribution of power in the society at large), protection of consumers against big business' practices, safeguarding democratic mechanism, protection of certain sectors of economy which bear big social importance (like e.g. agriculture, fisheries, forestry, transportation etc.), security of energy supply, natural environment protection, etc. ${ }^{17}$ Henceforward, as to summarize those listed objectives, it is right to use after Ignacio de León the term of 'social optimum'18.

Moreover, within the European Union there is another very important objective of competition law - namely European integration and single European market ${ }^{19}$. David J. Gerber names it correctly 'unification imperative, ${ }^{20}$. So the question may be posed how economic effectiveness and market integration can go together. Stephen Weatherill and Paul Beaumont rightly point that "Indeed, in the long term the two notions ought theoretically to be coterminous. Yet in the short term it is feasible that two objectives may clash" ${ }^{21}$.

The choice of priorities means a necessity of selecting legal instruments of realization of given objectives. The following question is a problem of relations between possible particular economic sector regulations and general competition regulation. A very good

\footnotetext{
15 See broad approach to the concept of perfect competition: MAKOWSKI, L., OSTROY, J.M., "Perfect Competition and the Creativity of the Market”, Journal of Economic Literature, Vol. 39/June 2001, p. 479 ff. See additionally wide considerations on perfect competition and workable competition (in): MEESE, A.J., “Monopolization, Exclusion, and the Theory of Firm”, Minnesota Law Review, Vol. 89/2005, pp. 772-808.

${ }^{16}$ See the concept of 'workable competition' in: CLARK, J.M., “Toward a Concept of Workable Competition”, The American Economic Review, No. 2 (Vol. 30)/1940, p. 241 ff. See additionally: DRAHOS, M., Convergence of Competition Laws and Policies in the European Community. Germany, Austria and Netherlands, The HagueLondon-Boston, 2001, pp. 40-41; and BISHOP, S., WALKER, M., Economics of E.C. Competition Law: Concepts, Application and Measurement, London-Dublin-Hong Kong, 1999, p. $13 \mathrm{ff}$.

17 See CINI, M., MCGOWAN, L., Competition Policy in the European Union, New York, 1998, p. 4. See additionally: AKMAN, P., supra, p. 25; FURSE, M., supra, p. 250; and: LEÓN DE, I., "The Dillema of Regulating International Competition under the WTO System“, European Competition Law Review, No. 3/1997, p. 163.

${ }^{18}$ LEÓN DE, I., ibidem.

${ }^{19}$ Once in the past Valentine Korah bitterly stated that „Integration has been elevated by the Commission and the Court to a goal in itself, more important than efficiency”. KORAH, V., EEC Competition Policy - Legal Form or Economic Efficiency, Current Legal Problems, Oxford, 1986, p. 91. The question appears, however, whether that statement is up-to-date at present. See additionally: SZYSZCZAK, E., CYGAN, A., Understanding EU Law, First Edition, London, 2005, p. 81 ff; BERGH VAN DEN, R.J., CAMESASCA, P.D., European Competition Law and Economisc: A Comparative Perspective, 2nd Edition, London, 2006, p. 46; KON, S., SCHAEFFER, F., "Parallel Imports of Pharmaceutical Products: A New Realism, or Back to Basics”, European Competition Law Review, No. 3/1997, p. 127; CRAIG, P., BÚRCA DE, G., EU Law. Text, Cases and Materials. Second Edition, Oxford 1998, p. 923; BISHOP, S., WALKER, M., supra, p. 3 ff; GERBER, D.J., Integration, Disintegration and the Protection of Competition: of Images, Stories and Myths, supra, p. 237 and p. 239; and GERBER, D.J., "The Transformation of European Community Competition Law?”, Harvard International Law Journal, , No. 1 (Vol. 35)/1994,, pp. 98100; WEATHERILL, S., BEAUMONT, P., EC Law. The essential guide to the legal workings of the European Community, London-New York-Ringwood-Toronto-Auckland, 1993, p. 594.

${ }^{20}$ GERBER, D.J., “The Transformation of European Community Competition Law?”, supra, p. 98.

${ }^{21}$ WEATHERILL, S., BEAUMONT, P., supra, p. 594.
}

Revista de Estudios Jurídicos no 15/2015(Segunda Época)

ISSN 2340-5066. Universidad de Jaén (España)

Versión electrónica: rej.ujaen.es 
example of such relation is the European Union's agriculture sector. So when answering the question about competition in the EU agriculture sector it is indispensable to analyze how far the general competition rules are binding for the EU agriculture businesses (material scope of general competition rules).

For the purpose of this article the EU competition rules are understood as art. 101 and art. 102 of TFEU. The question of state aid (viz. articles 107-108 of TFEU), although of a big relevance, remains outside present considerations. Without any doubt, the latter mentioned question deserves a separate broad legal analysis.

\section{EU AGRICULTURAL POLICY. MATERIAL AND PERSONAL SCOPE. MAIN OBJECTIVES}

Common Agricultural Policy, introduced in 1962, is one of the EU's oldest policies ${ }^{22}$. Primarily, CAP had such objectives as to increase agricultural production, to stabilize the agricultural markets, to provide for food security for citizens of the Member States, to protect farmers families' standard and quality of life, to maintain reasonable prices for food products, etc. All those mentioned objectives related to the post-World War II conditions, characterized by shortage of food, hunger and other social problems. Now-a-days the objectives have changed in a natural way. Now the Policy encompasses such aims as animal welfare, farmer training, land management, environmental development and control of pollution, rural development, climate stability and even securing biodiversity and protection of wildlife ${ }^{23}$.

According to art. 38 sec. 1 TFEU agricultural products mean the products of the soil, of stockfarming and of fisheries and products of first-stage processing directly related to these products. It must be noted that the term 'products of first-stage processing' is not defined by the Treaty. Under the judicature (case law; French: jurisprudence) of Court of Justice of the European Union when approaching the term of 'products of first-stage processing' the most important is the factor of economic relation between basis agricultural product and processed product. "The concept of 'products of first-stage processing directly related' to basic products must, accordingly, be interpreted as implying a clear economic interdependence between basic products and products resulting from a productive process, irrespective of the number of operations involved therein. Processed products which have undergone a productive process, the cost of which is such that the price of the basic agricultural raw materials becomes a completely marginal cost, are therefore excluded" 24 . Consequently, the crucial role is played

\footnotetext{
${ }^{22}$ See on the history of agricultural sector in Europe and on the beginning of CAP in, inter alia, KAPTEYN, P.J.G., THEMAAT VAN, P.VL., Introduction to the Law of the European Communities. From Maastricht to Amsterdam. Third Edition, London-The Hague-Boston, 1998, pp. 1128-1134. See also: TROITINO, D.R., CHOCHIA, A., "The Common Agricultural Policy, It's Role in European Integration and Influence on the Enlargements of the Organization (Case Study: Georgia)”, International and Comparative Law Review, No. 1 (Vol. 13)/2013, pp. 3742.

${ }^{23}$ See: READ P.K., "28 Countries and One Common Agricultural Policy: European Family Farmers and Agricultural Reform. Foodtank 19 May 2014”, retrieved on January 28, 2015, in http://foodtank.com/news/2014/05/counries-and-one-common-agricultural-policy-eu; “Overview of CAP Reform 2014-2020, European Commission, Agricultural Policy Perspectives Brief, No. 5/December 2013”, pp.1-2, retrieved on January 28, 2015, in http://ec.europa.eu/agriculture/policy-perspectives/policy-briefs/05_en.pdf; see also: "New EU reforms fail European wildlife. University of Cambridge”, retrieved on January 28, 2015, in http://www.cam.ac.uk/research/news/new-eu-reforms-fail-european-wildlife.

${ }^{24}$ See Case 185/73 Hauptzollamt Bielefeld v. Offene Handelgesellschaft in Firma H.C. König, sec. 13. E.C.R.
} 
by comparison of cost of basic agricultural product with cost of products of first-stage processing.

In terms of personal scope, the EU agricultural policy encompasses farmers (farming producers). The term 'farmer' is not defined by the Treaty. It is widely accepted that a farmer means a person bearing 3 characteristics: firstly, there must be a direct economic management over production unit in the agricultural sector. Secondly, there must be direct risk related to agricultural activity borne by a person. Thirdly, in case of natural person, there must be right to social security benefits under a given Member State law.

According to Council Regulation (EC) No. 73/2009 of 19 January 2009 establishing common rules for direct support schemes for farmers under the common agricultural policy and establishing certain support schemes for farmers, amending Regulations (EC) No 1290/2005, (EC) No 247/2006, (EC) No 378/2007 and repealing Regulation (EC) No $1782 / 2003^{25}$, 'farmer' means natural or legal person, or a group of natural or legal persons, whatever legal status is granted to the group and its members by national law, whose holding is situated within Community territory, as defined in Article 299 of the Treaty, and who exercises an agricultural activity (art. 2 point a of the Council Regulation No 73/2009). The term 'holding' means all the production units managed by a farmer situated within the territory of the same Member State (art. 2 point b f the Council Regulation No 73/2009). 'Agricultural activity' means the production, rearing or growing of agricultural products including harvesting, milking, breeding animals and keeping animals for farming purposes, or maintaining the land in good agricultural and environmental condition (art. 2 point c of the Council Regulation No 73/2009). Moreover, besides above terms, 'agricultural area' means any area taken up by arable land, permanent pasture or permanent crops (art. 2 point $h$ of the Council Regulation No 73/2009) ${ }^{26}$.

In the past, European law defined the term 'farmer' in a different way. For example, under the Council Directive 72/159/EEC of 17 April 1972 on the modernization of farms ${ }^{27}$ farmer meant a person who: firstly, practises farming as his main occupation; secondly, possesses adequate occupational skill and competence; thirdly, undertakes that from the start of the development plan he will keep accounts as defined in article 11 of Directive; and fourthly, draws up a plan for the development of the farm business which satisfies the conditions laid down in article 4 of Directive. Later regulations demanded a farmer to gain at least half of his/her income from agricultural activities and to devote at least half of labour time for agricultural activities ${ }^{28}$.

At present, it is quite clear that farmer may mean both natural and legal person. Not that far ago an answer to the question whether legal person may be treated as farmer under European regulation was not that obvious. In Case 312/85 SpA Villa Banfi v. Regione Toscana and others the Italian Government claimed that 'a farmer practising farming as his main occupation', means, apart from natural persons, only agricultural cooperatives and

1974, 607; see additionally Case 85/77 Societa Santa Anna v INPS, E.C.R. 1978, 527.

${ }^{25}$ OJ L 30, 31.01.2009, p. 16.

${ }^{26}$ Same definitions were provided by previous Council Regulation No. 1782/2003 of 29 September 2003 establishing common rules for direct support schemes under the common agricultural policy and establishing certain support schemes for farmers, art. 2. OJ L 270, 21.10.2003, p. 1.

${ }^{27}$ OJ L 96, 23.04.1972, p. 1.

${ }^{28}$ See JURCEWICZ., A., KOZŁOWSKA, B., TOMKIEWICZ., E., Wspólna Polityka Rolna. Zagadnienia prawne, Warszawa, 2004, p. 33. 
farmers' associations. So the Court clearly stated in its Judgment of 18 December 1986 that 'farmer' means not only natural person, but legal person as well ${ }^{29}$.

The formal objectives of the CAP are prescribed by art. 39 sec. 1 of TFUE. Firstly, the Common Agricultural Policy shall intend to increase agricultural productivity by promoting technical progress and by ensuring the rational development of agricultural production and the optimum utilisation of the factors of production, in particular labour. Secondly, it shall guarantee a fair standard of living for all members of the agricultural community. According to the Treaty it shall be realized, inter alia, by means of increasing the individual earnings of all persons engaged in agriculture. Thirdly, it shall guarantee stabilization of markets. Fourthly, it shall guarantee reasonable prices for all consumers. In the course of accomplishment of all listed objectives, the particular characteristics of the agricultural sector shall be taken into consideration, like: the very special nature of agricultural activity, which results from the social structure of agriculture and from structural and natural disparities between the various agricultural regions; the need to effect the appropriate adjustments gradually; the fact that in all Member States agriculture constitutes a sector closely linked with the economy as a whole; and the fact that agriculture constitutes a sector closely linked with the economy as a whole (art. 39 sec. 2 of TFEU).

It comes out quite transparently from the above that agricultural policy is to achieve goals of economic nature (e.g. growth of productivity in agriculture) and of a socio-political nature (e.g. maintenance of adequate standard of living and growth of farmers' income) at the same time. Those goals rest in a blatant contradiction with each other ${ }^{30}$. According to the Court of Justice a preference in terms of accomplishment of certain given objectives prescribed by the Treaty rest within the competence of the Community's institutions. The Court of Justice named such preferences 'temporary priorities, ${ }^{31}$.

The modern objectives of the EU policy in the agriculture sector are quite more complex than it was in the beginning. For example, Regulation No. 1305/2013 of the European Parliament and of the Council of 17 December 2013 on support for rural development by the European Agricultural Fund for Rural Development (EAFRD) and repealing Council Regulation (EC) No. 1698/2005 ${ }^{32}$ defines the mission of EAFRD as “... the development of a Union agricultural sector that is more territorially and environmentally balanced, climate-friendly and resilient and competitive and innovative. It shall also contribute to the development of rural territories" (art. 3 of Regulation No. 1305/2013). Then, the objectives are defined as: fostering the competitiveness of agriculture, ensuring the sustainable management of natural resources, and climate action, and achieving a balanced territorial development of rural economies and communities including the creation and maintenance of employment (art. 4 of Regulation No. 1305/2013). Moreover, among the priorities are: fostering knowledge transfer and innovation in agriculture, forestry, and rural areas; enhancing farm viability and competitiveness of all types of agriculture in all regions and promoting innovative farm technologies and the sustainable management of forests;

\footnotetext{
${ }^{29}$ See Case 312/85 SpA Villa Banfi, sections 10-11. E.C.R. 1986, 4039.

${ }^{30}$ See numerous European courts’ cases: Case 5/67 W. Beus GmbH v. Hauptzollamt München, E.C.R. 1968, 83; Case 5/73 Balkan-Import-Export GmbH v Hauptzollamt Berlin-Packhof, E.C.R. 1973, 1091; Case 71/74 Nederlandse Vereniging voor Fruit en Groentenimporthandel and others (FRUBO) v. Commission, E.C.R. 1975, 563.

${ }^{31}$ See Case 5/73 Balkan-Import-Export GmbH v. Hauptzollamt Berlin-Packhof, E.C.R. 1973, 1112.

32 OJ L 347, 20.12.2013, p. 487.
}

Revista de Estudios Jurídicos no 15/2015(Segunda Época)

ISSN 2340-5066. Universidad de Jaén (España)

Versión electrónica: rej.ujaen.es 
promoting food chain organisation, including processing and marketing of agricultural products, animal welfare and risk management in agriculture; restoring, preserving and enhancing ecosystems related to agriculture and forestry; promoting resource efficiency and supporting the shift towards a low carbon and climate resilient economy in agriculture, food and forestry sectors; and promoting social inclusion, poverty reduction and economic development in rural areas (art. 5 of Regulation No. 1305/2013) ${ }^{33}$. All those priorities shall contribute to the cross-cutting objectives of innovation, environment and climate change mitigation and adaptation (art. 5 in fine). Going further, the Commission Delegated Regulation (EU) No 807/2014 of 11 March 2014 supplementing Regulation (EU) No 1305/2013 of the European Parliament and of the Council on support for rural development by the European Agricultural Fund for Rural Development (EAFRD) and introducing transitional provisions ${ }^{34}$ provides for a long list of considerations of the regulation at stake, and among them there are such values as: young farmers; farm and forest exchange schemes and visits; farm and business development; afforestation and creation of woodland; agrienvironment-climate; conservation of genetic resources in agriculture and in forestry; animal welfare; cooperation (art. 1 of Commission Delegated Regulation No 807/2014).

As one can see, the variety of the objectives, aims, tasks, etc. has changed tremendously over last years. It has become much more compound and differentiated.

\section{COMPETITION RULES IN THE EU AGRICULTURAL SECTOR}

Generally speaking, under the European Union courts' judicature all the general competition rules are binding upon every sector of the economy irrespectively, as far as TFEU does not provide for a particular exclusion ${ }^{35,36}$.

As far as agricultural sector concerned, the Treaty provides for an explicit exclusion from EU competition rules. According to art. 42 of TFEU all competition rules from articles 101-109 TFEU shall apply to production of and trade in agricultural products only to the extent determined by the European Parliament and the Council in compliance with general principles and objectives of the Common Agricultural Policy (CAP) and Rural Development $^{37}$. The mentioned regulation gives to the European Parliament and the Commission a competence to enact rules introducing Common Agricultural Policy, providing mentioned institutions with quite wide discretion ${ }^{38}$.

It is worth to note that the exclusion from general rules on competition provided for agricultural sector is the only one explicit exclusion introduced by TFEU ${ }^{39}$.

\footnotetext{
${ }^{33}$ In fact those listed priorities are much more complex under art. 5 of Regulation No. 1305/2013 (each of listed priorities includes a list of areas of a special focus).

${ }^{34}$ OJ L 227, 31.07.2014, p. 1.

${ }^{35}$ See Joined Cases 209-213/84 Ministère Public v. Asjès and others. E.C.R. 1986, 1425. See also: Ali Nikpay, Jonathan Faull in: Jonathan Faull, Ali Nikpay, ed., The EC Law of Competition, Oxford 1999, p. 62.

${ }^{36}$ See on terms: 'exclusion', 'exemption' and 'exception' in: TAYLOR, P.M., E.C. and U.K. Competition Law and Compliance: A Practical Guide, London, 1999, p. 24; and TURNER, J.D.C., "The U.K. Competition Act 1998 and Private Rights”, European Intellectual Property Review, No. 4 (Vol. 21)/1999, p. 182.

${ }^{37}$ See MATHIJSEN, P.S.R.F., A Guide to European Union Law. Ninth Edition, London, 2007, p. 348-349.

${ }^{38}$ See for instance Case 139/79 Maizena GmbH v Council, sec. 23. E.C.R.1980, 3393.

${ }^{39}$ Nevertheless, it is possible to point military industry ('production of or trade in arms, munitions and war material'), or not that far ago transportation sector, as examples of other exceptions, as well. See art. 346 sec. 1 point $b$ of TFEU.
} 
Moreover, Common Agricultural Policy and Rural Development regulation is a specific regulation (lex specialis) next to common market regulation. So, consequently, provisions of articles 101 and 102 are applicable to the production and marketing of agricultural products as far as they are not yet subject to a common organization of the market. In another words, the general rules on competition are applicable to the agricultural sector and Common Agricultural Policy and Rural Development only in the lack of a specific particular regulation of the agricultural market ${ }^{40}$.

Therefore, the objectives of EU agricultural policy prevail over the general competition rules (Case 139/79 Maizena GmbH v. Council).

By those described above means there is so-called positive integration model accomplished within the EU agricultural sector.

At present, a specific scope of the exclusion from the EU general competition rules is regulated by Council Regulation (EC) No. 1184/2006 of 24 July 2006 applying certain rules of competition to the production of and trade in certain agricultural products ${ }^{41}$. Mentioned Regulation repealed previous Regulation No. 26/62 of 4 April 1962 r. $^{42}$

According to art. 2 of Council Regulation No. 1184/2006, the prohibition laid down in art. 101 sec. 1 of TFEU (prohibition of anticompetitive agreements, concerted practices and decisions by an association of undertakings) is not applicable to agreements, decisions and practices referred which form an integral part of a national market organisation or are necessary for attainment of the objectives set out in article 39 of the Treaty. Prohibition in art. 101 sec. 1 TFEU shall not apply, in particular, to agreements, decisions and practices of farmers, farmers' associations, or associations of such associations belonging to a single Member State which concern the production or sale of agricultural products or the use of joint facilities for the storage, treatment or processing of agricultural products, and under which there is no obligation to charge identical prices, unless the Commission finds that competition is thereby excluded or that the objectives of Article 39 of the Treaty are jeopardised.

The Court of Justice ruled, on the ground of previous regulation of the subject matter laid down by Regulation No. 26 of 4 April 1962 where there were words “...in particular...” as well (art. 2 sec. 1 of Regulation 26), that given phrase is not merely of an illustrative nature and it does constitute a separate exclusion in fact ${ }^{43}$. Henceforward, taking into consideration that those two regulations have identical wording (viz. phrase “...in particular”), it is possible to claim that there are three distinctive exclusions furnished by Regulation No. 1184/2006, as well.

The first exclusion refers to national agricultural market organizations. The national organization is defined as a totality of legal devices, placing the regulation of the market in

\footnotetext{
${ }^{40}$ See numerous European courts' cases like: Case 91/78 Hansen GmbH \& Co. v. Hauptzollamt Flensburg, E.C.R. 1979, 935 (especially sections 10-11); Case 177/78 Pigs and Bacon Commission v. McCarren and Company Limited, E.C.R. 1979, 2169; Case 68/86 United Kingdom v. Commission (Agricultural Hormones), E.C.R. 1988, 855; Case C-331/88 The Queen v. The Minister of Agriculture, ex. p. Fédération Européenne de la Santé Animale (FEDESA) and others, E.C.R. 1990, I-4023.

${ }^{41}$ OJ L 214, 4.08.2006, p. 7.

${ }^{42}$ Council Regulation No 26 of 4 April 1962 applying certain rules of competition to production of and trade in agricultural products. OJ B 30, 20.04.1962, p. 993.

${ }^{43}$ See Joint Cases C-319/93, C-40/94, and C-224/94 Hendrik Evert Dijkstra v. Friesland (Frico Domo) Coöperatie BA and Cornelis van Roessel and others v. De coöperatieve vereniging Zuivelcoöperatie Campina Melkunie VA and Willem de Bie and others v. De Coöperatieve Zuivelcoöperatie Campina Melkunie BA., E.C.R.1995, I-4471. CMLR 1996, No. 5, p. 178.
} 
the products in question under the control of the public authority, with a view to ensuring, by means of an increase in productivity and of optimum utilization of the factors of production, in particular of manpower, a fair standard of living for producers, the stabilization of markets, the assurance of supplies and reasonable prices to consumers ${ }^{44}$. Consequently, the national organization is understood as an organization of a national level which constitutes an integral part of national system of organizing agricultural markets with aims as defined in art. 39 TFEU. The decisions and agreements of the organizations must implement the state regulation of the market concerned. Therefore, they ought to form an integral part of the national market organization in question ${ }^{45}$. The lack of an organization of the market at national level precludes a limine a legal possibility to call upon the exclusion ${ }^{46}$. In addition, this exclusion may be applicable only in case when there is no common EU market organization in the particular agricultural $\operatorname{sector}^{47}$.

The second exclusion refers to agreements, decisions and practices which are indispensable to accomplish the objectives of Common Agricultural Policy as furnished by art. 39 TFEU. The Court of Justice ruled, on the ground of previous Regulation No. 26, that an organization shall intend to achieve all the objectives prescribed in art. 39 TFEU, not only a few of them ${ }^{48}$. This exclusion may be applicable only of case of lack of EU market organization in the particular agricultural sector, too ${ }^{49}$.

The third, last exclusion from art. $101 \mathrm{sec} 1$ TFEU prohibition refers specifically to farmers' organizations and associations. This exclusion encompasses agreements between/among farmers and farmers' cooperatives ${ }^{50}$. Consequently, only farmers may be members of mentioned organizations, associations or cooperatives. Other entities, like intermediaries or wholesalers, are here excluded ${ }^{51}$.

Nevertheless, there are certain limits of this exclusion from art. 101 TFEU prohibition. Such agreements and other practices cannot destroy totally the competition on the market, and they cannot contradict the objectives of Common Agricultural Policy as laid down in art. 39 TFEU. According to the Court of Justice the articles of association (statutes) which provided for exclusive supply from their members and which established a high fee for a withdrawal from a cooperative were not covered by the exclusion ${ }^{52}$.

\footnotetext{
${ }^{44}$ See Case 48/74 Charmasson v. Minister for Economic Affairs and Finance ECR 1974, 1383. Additionally, see Commission Decision of 18 December 1987 No. 88/109/EEC (IV/31.735, New Potatoes), OJ L 59, 4.03.1988, p. 25 (see page 28). See also Case 71/74 Nederlandse Vereniging voor Fruit en Groentenimporthandel and others (FRUBO) v. Commission, E.C.R. 1974, 563.

${ }^{45}$ See Commission Decision of 18 December 1987 No. 88/109/EEC (IV/31.735, New Potatoes), ibidem, p. 29.

${ }^{46}$ See Commission Decision of 25 July 1974 No. 74/433/EEC (FRUBO), Part III sec. 2; E.C.R. 237, 29.08.1974, p. 16.

${ }^{47}$ See Commission Decision of 2 December 1977 No. 78/66/EEC (Groupement d’Expertation du Léon „GREX”Cauliflowers), Part III point 1. OJ L 21, 26.01.1978, p. 23.

${ }^{48}$ See Case 71/74 (FRUBO).

${ }^{49}$ See, for example, Case C-265/97P Coöperatieve Vereniging De Verenigde Bloemenveilingen Aalsmeer BA (VBA) v. Florimex BV and Vereniging van Groothandelaren in Bloemkwekerijproducten (VGB), E.C.R. 2000, I2061.

${ }^{50}$ See Case C-399/93 H. G. Oude Luttikhuis and others v. Verenigde Coöperatieve Melkindustrie Coberco BA. E.C.R. 1995, I-4515. CMLR 1996 No. 5, p. 178.

${ }^{51}$ Intermediaries in the agricultural markets are undertakings, but they are not farmers as such. See Commission Decision No. 74/433/EEC (FRUBO), supra, Part III sec. 1.

${ }^{52}$ See Case C-399/93, supra. See additionally Joint Cases C-319/93, C-40/94, and C-224/94, supra. On the other hand, it is worth to note that contributions levied compulsory for all members of the organizations (or traders),
} 
Under art. 2 sec. 2 of Council Regulation No 1184/2006 the Commission shall have an exclusive power, subject to review by the Court of Justice, to determine, by decision which shall be published, which agreements, decisions and practices fulfill the conditions specified in this Regulation. Such analysis of mentioned practices take place on the notion of any party or parties with an interest in it, or on the notion of EU institutions, or the Commission may take up the case on its own initiative (ex officio).

It must be underlined that of Council Regulation No. 1184/2006, like the previous Regulation No. 26, does not provide for any exclusion from the prohibition against abuse of dominant position as laid down in art. 102 of TFEU ${ }^{53}$.

EU organization of the agricultural markets is provided now-a-days by Regulation (EU) No. 1308/2013 of the European Parliament and of the Council of 17 December 2013 establishing a common organisation of the markets in agricultural products and repealing Council Regulations (EEC) No 922/72, (EEC) No 234/79, (EC) No 1037/2001 and (EC) No $1234 / 2007^{54}$. Under the mentioned Regulation agricultural products are divided into (art. 1 of Regulation No. 1308/2013): cereals, rice, sugar, dried fodder, seeds hops, olive oil and table olives, flax and hemp, fruit and vegetables, processed fruit and vegetable products, bananas, wine, live trees and other plants, bulbs, roots and the like, cut flowers and ornamental foliage, tobacco, beef and veal, milk and milk products, pigmeat, sheepmeat and goatmeat, eggs, poultrymeat, ethyl alcohol of agricultural origin, apiculture products, silkworms, and other products (like horses, asses, mules and hinnies, coconuts, Brazil nuts and cashew nuts, fresh or dried, whether or not shelled or peeled, other nuts, vanilla, cinnamon, cane sugar, other fermented beverages like for example, cider, perry, mead, etc. etc.).

For instance, in the milk market (so-called 'Milk Package') under art. 148 of Regulation No. 1308/2013 Member States have the possibility to make written contracts between farmers and processors compulsory and to oblige purchasers of milk to offer farmers a minimum contract duration. Those mentioned contracts lay down the responsibilities of operators in the dairy chain, increase awareness of market signals, improve price transmission, adapt supply to demand and avoid certain unfair commercial practices. Furthermore, these contracts should be made in advance of delivery and contain specific elements such as the price, volume, duration, details concerning payment, collection and rules for force majeure. All contract clauses have to be freely negotiated between the parties. Farmers have the right to refuse an offer of a minimum duration in a contract. Deliveries by a farmer-member to his cooperative are exempted from this contract obligation if the statutes or rules of the coop contain provisions that have similar effects as the prescribed contract. It is rightly stated that "After abolition of the milk quota system, they are a useful tool for

moreover contributions that are rendered with administrative measures, are not regarded as state aid under the Treaty. See: Case C-345/02 Pearle BV and Others v. Hoofdbedrijfschap Ambachten, E.C.R. 2004, I-7139; and C-677/11 Doux Élevage SNC, Coopérative agricole UKL-ARREE v. Ministère de l'Agriculture, de l'Alimentation, de la Pêche, de la Ruralité et de l’Aménagement du territoire, Comité interprofessionnel de la dinde française (CIDEF), OJ C 225, 3.08.2013, p. 21, E.C.R. 2013.

${ }^{53}$ See JURCEWICZ., A., KOZŁOWSKA, B., TOMKIEWICZ., E., supra, p. 38. See additionally WHISH, R., Competition Law, Fifth Edition, Lexis Nexis UK, 2003, p. 921. See also Case T-70/92 and T-71/92 Florimex BV and Vereniging van Groothandelaren in Bloemkwekerijprodukten v. Commission, E.C.R. 1997, II-693, and following Case C-265/97P, E.C.R. 2000, I-2061.

${ }^{54}$ OJ L 347, 20.12.2013, 671.

Revista de Estudios Jurídicos no 15/2015(Segunda Época)

ISSN 2340-5066. Universidad de Jaén (España)

Versión electrónica: rej.ujaen.es 
producers and processors to plan their production volumes" 55 .

The collective bargaining in the milk sector is regulated by art. 149 of Regulation No. 1308/2013. This rule reinforces the bargaining power of milk producers. Farmers can join together in producer organisations (PO) that can negotiate collectively the contracts terms including the price of the raw milk. The volume of milk that a PO can negotiate is bound by certain clearly defined limits (i.e. 3.5\% of the EU production, 33\% of the national production of the Member State). Nevertheless, deliveries by member farmers to their processing cooperatives are not allowed to be subject of joint negotiations. But collecting cooperatives can form producer organisations (Pos) which can negotiate collectively with processors.

The producers organizations and their recognition procedure by Member States are regulated by arts. 152-155 of Regulation No. 1308/2013. The objectives of producers organizations are prescribed by art. 152 sec. 1 (c). Among those objectives there are: ensuring that production is planned and adjusted to demand, particularly in terms of quality and quantity; concentration of supply and the placing on the market of the products produced by its members, including through direct marketing; optimising production costs and returns on investments in response to environmental and animal welfare standards, and stabilising producer prices; carrying out research and developing initiatives on sustainable production methods, innovative practices, economic competitiveness and market developments; promoting, and providing technical assistance for, the use of environmentally sound cultivation practices and production techniques, and sound animal welfare practices and techniques; promoting, and providing technical assistance for, the use of production standards, improving product quality and developing products with a protected designation of origin, with a protected geographical indication or covered by a national quality label; the management of by-products and of waste in particular to protect the quality of water, soil and landscape and preserving or encouraging biodiversity; contributing to a sustainable use of natural resources and to climate change mitigation; developing initiatives in the area of promotion and marketing; managing of the mutual funds; and providing the necessary technical assistance for the use of the futures markets and of insurance schemes.

Generally, all recognized POs focus on cow's milk, except one solely for ewe's milk in Spain. A large number of the total 228 POs in the EU dairy sector, notably in Germany and Italy, already existed before the Milk Package came into force. However, the number recognitions has increased in $2013^{56}$.

Producers organizations may form associations, which shall be recognized by Member States (art. 156 of Regulation No. 1308/2013).

Furthermore, there is a possibility to form Interbranch Organizations which are constituted of representatives of economic activities linked to the production and to at least one of the following stages of the supply chain: the processing of or trade in, including distribution of, products in one or more sectors. The Interbranch Organizations have to be formed on the initiative of all or some of the organisations or associations which constitute them. Moreover, they ought to pursue specific objectives listed by art. 157 sec. 1 (c) of Regulation No. 1308/2013 (like e.g. helping to coordinate better the way the products are placed on the market, in particular by means of research and market studies, or exploring potential export markets).

\footnotetext{
55 "Report from the Commission to the European Parliament and the Council. Development of the dairy market situation and the operation of the 'Milk Package' provisions”, Brussels 13.06.2014, COM(2014) 354 final, pp. 3-5.

${ }^{56}$ Ibidem, pp. 5-6.
} 
All described above different farmer associations and their specific activities in the milk market would fall within the scope of prohibition of art. 101 sec. TFEU. However, they are excluded from the prohibition under art. 2 sec. 1 of Council Regulation No. 1184/2006.

\section{Latest developments within EU agricultural policy. Final conclusions}

The exclusion of EU agricultural sector and farmers and their organizations from the prohibition of anticompetitive agreements is aimed directly to protect European farmers against a fierce global competition and against powerful undertakings which purchase (purchasing centers) and process agricultural products.

It is relevant in this context that small family farms account for 95 percent of all farms in the EU. In addition to that, small farms under two hectares (five acres) constitute approximately 50 percent of all 12.2 million farms all over the EU. At the same time big farms of over 200 hectares (247 acres) constitute 50 percent of farmland and only 2.7 percent of overall farms number. This led to transfer of big amount of funding generally to large farms, as historically the funding was connected with acreage with more intensive production. Now it is to be changed. The funds shall be more available to small farms.

Another problem relates to the average age of family farmers, which is over 50 . at present. This is a big problem of a demographic nature ${ }^{57}$. Thus it is necessary to support young farmers in many ways as to provide for incentives for them to make them stay on their farms.

It is the nature of the agricultural sector that farmers, especially small family kind of farms, are weak and without an enough contractual power vis-á-vis economically powerful and strong food and agricultural industry ${ }^{58}$. Consequently, it seems quite justified politically and socially to provide farmers with a certain privilege (kind of 'positive discrimination' right) which may enforce the farmers' position next to big business units. Withal, such an exclusion from general rules on competition (specifically anticompetitive agreements prohibition) has been introduced by many countries all over the world, including USA, since early 20. of the XX century ${ }^{59}$.

Consequently, certain limits to competition on agricultural markets seem to be justifiable. The necessity to promote and to protect small family farms as an element of democratic and liberal state is recognized in many countries ${ }^{60}$. Such an attitude may be compared with special approach towards small and medium undertakings. However, it is essential to note that there are many attempts towards deregulation of agricultural markets, both in the USA ${ }^{61}$ and within the $\mathrm{EU}^{62}$. Mentioned deregulation prima facie should mean more free market and more competition

\footnotetext{
${ }^{57}$ See READ, P.K., supra.

${ }^{58}$ See "Competition: Commission launches study on choice and innovation in food sector. European Commission Press Release”, 11 December 2012, IP/12/1356.

${ }^{59}$ See American Clayton Act of 1914, October 15, 1914, Ch. 323, §§ 1-15, 38 Stat. 730.15 U.S.C. Sections 12-27; and Capper-Volstead Act of 1922, 42 Stat. 388 (1922). See in addition COHEN, D., GERBER, A.B., "Organized Labor or the Sherman Act”, National Lawyers Guild Quarterly, Vol. 2/April 1939, p. 106 ff; and DABBAH, M.M., International and Comparative Competition Law, Cambridge, New York, 2010, pp. 244-245.

${ }^{60}$ See LAUCK, J., American Agriculture and the Problem of Monopoly: The Political Economy of Grain Belt Farming 1953-1980, The University of Nebraska Press, 2000, p. 4.

${ }^{61}$ American Federal Agriculture Improvement and Reform Act of 1996 (P.L. 104-127), called "Freedom to Farm Act”. See LAUCK, J., ibidem, p. 4 ff, especially p. $21 \mathrm{ff.}$

62 See: “Agriculture and Food. Overview”, retrieved on October 5, 2014, in http://ec.europa.eu/competition/sectors/agriculture/overview_en.html.
} 
inside the agricultural sector. The latest crucial reform of EU agricultural policy was began in 2013. As the Commission explains in its document titled 'Overview of CAP Reform 20142020': “To achieve the long-term goals for the CAP, the reform focuses on the competitiveness and sustainability of the agricultural sector by improving the targeting and efficiency of policy instruments”. One of key elements with aim to enhance competitiveness of the EU agriculture is the gradual removal of production constraints (limits) in certain markets, viz. sugar (sugar quotas shall be abolished in 2017), diary (milk and butter; diary quotas expire in 2015), and wine (wine market shall be opened in 2018) ${ }^{63}$. At the same time producers co-operation under both pillars of the CAP shall be reinforced by different measures. The legal framework extends the possibility for collective bargaining (in many agricultural markets) and for delivery contract (in all agricultural markets) to producers organizations, associations of organizations and interbranch organizations. Moreover, there are additional exclusions from general competition rules in periods of severe market imbalance for certain actions, like market withdrawal or storage. There are many measures of support for establishment of farmer (producer) groups and for cooperation, creation of local food systems and cutting supply chain in food markets ${ }^{64}$. So, paradoxically, strengthening the competition in the EU agriculture and making the sector more market-oriented does not necessarily means enforcing general competition rules in the sector. And 'deregulation' does not mean opening of the market with less regulation. Therefore, agriculture is not left merely to market forces. In these terms, the 'Milk Package' is a good example of a new specific regulation of the market. The CAP reform 2014-2020 does in fact provide for more state interventionism. According to liberal economists the best de lege ferenda solution might be the full opening of the market, meaning abrogation of the whole CAP (including rural development). That may result, however, with bankruptcy of entire agricultural sector in EU. It must be underlined, that the present EU interventionism focuses on different aims that it used to in the past ${ }^{65}$. At the same time the variety of means are adjusted. So the Policy became more 'intelligent'. It is also visible that the reform at stake is an attempt to rationalize and optimize the CAP to make it compatible with the modern agriculture and its needs in the modern world.

\footnotetext{
63 “Overview of CAP Reform 2014-2020”, supra, p. 5.

${ }^{64}$ Ibidem, pp. 5-6.

65 See ibidem, pp. 2-3: "The New Policy continues along this reform path, moving from product to producer support and now to a more land-based approach. This is in response to the challenges facing the sector, many of which are driven by factors that are external to agriculture. (...) Since the role of the CAP is to provide a policy framework that supports and encourages producers to address these challenges while remaining coherent with other EU policies, this translates into three long-term CAP objectives: viable food production, sustainable management of natural resources and climate action and balanced territorial development. To achieve these longterm goals, the existing CAP instruments had to be adapted. The reform therefore focused on the operational objectives of delivering more effective policy instruments, designed to improve the competitiveness of the agricultural sector and its sustainability over the long term”. In short, EU agriculture needs to attain higher levels of production of safe and quality food, while preserving the natural resources that agricultural productivity depends upon. This can only be achieved by a competitive and viable agricultural sector operating within a properly functioning supply chain and which contributes to the maintenance of a thriving rural economy. In addition, to achieve these long-term goals, better targeting of the available CAP budget will be needed". See additionally: TROITINO, D.R., CHOCHIA, A., supra, pp. 47-49.
} 